\title{
Evidence of Luminous Bacterial Symbionts in the Light Organs of Myctophid and Stomiiform Fishes
}

\author{
DAVID FORAN \\ Department of Biology, The University of Michigan, \\ Ann Arbor, Michigan 48109
}

\begin{abstract}
The myctophids and stomiiforms represent two common groups of luminous fishes, but the source of luminescence in these animals has remained undetermined. In this study, labeled luciferase gene fragments from luminous marine bacteria were used to probe DNA isolated from specific fish tissues. A positive signal was obtained from skin DNA in all luminous fishes examined, whereas muscle DNA gave a weaker signal and brain DNA was negative. This observation is consistent with luminous bacteria acting as the light source in myctophids and stomiiforms and argues against the genes necessary for luminescence residing on the fish chromosomes. To confirm the location of this signal, a bacterial probe was hybridized in situ to sections of a stomiiform. A strong signal was generated directly over specific regions of the fish light organs, whereas no signal was found over other internal or epidermal tissues of the fish. Taken together, these data provide the first indication that luminous bacterial symbionts exist in myctophids and stomiiforms and that these symbionts account for luminescence in these fishes.
\end{abstract}

Luminous fishes make up a major portion of the oceans' mid- and deep-water fauna. However, in only a fraction of these is the mechanism of luminescence well understood (reviewed by Harvey, '52; Herring and Morin, '78; Hastings and Nealson, ' 81 ; Hastings, ' 83 ). Where it is well characterized, as in species of Physiculus, the Ceratioidae, and the Anomalopidae, among others, fish luminescence depends on a symbiotic relationship between the animal and one of a number of luminous bacterial species that not only exist in the light organs of the fish but are also common in the oceans' waters (Harvey, '52; Hastings and Nealson, '81). Such bacterial symbionts have been confirmed in cultures generated from light organs, by microscopy (e.g., Bassot, '66); through assays for the enzyme responsible for luminescence, bacterial luciferase (Leisman et al., '80); and in one case by molecular techniques (Haygood and Cohn, '86). In these fishes, light emission from the constant bacterial glow is controlled by mechanical means, such as a lid pulled over the light organ (Photoblepharon).

This is not the case, however, in two common groups of luminous fishes, the myctophids and stomiiforms, where luminescence appears to be under physiological control and ranges from a slowly propagated glow to flashes occurring several times per second (Harvey, '52). Luminescence in the myctophids and stomiiforms arises from photophores, small, often innervated light organs, which are generally found in one or two ventral rows on the skin and may occur elsewhere on the body. Further, some stomiiforms have a luminous barbel, and both groups may contain luminous patches or scales (e.g., Harvey, '52; Jorgensen and Munk, '79). This array of light organs can be used as lures, for schooling purposes, or as defense mechanisms; light organs may also be secondary sexual characters.

In spite of the vast quantity of research directed towards myctophids and stomiiforms, there are still few or no firm results regarding their method or methods of luminescence. Extensive microscopic studies of the light organs of these fishes give no indication of the presence of symbiotic bacteria (e.g., Bassot, '66; Herring and Morin, '78; Jorgensen and Munk, '79). Further, a luciferase has not been isolated from these fishes, nor from any fish that does not harbor luminous bacteria. Some positive results have been obtained by assaying preparations of luminous fishes for the luciferase of coelenterates (reviewed by Hastings, '83), but this assay is positive in a broad range of organisms (Hastings, '83) and no successful attempts have been made to isolate the enzyme.

\footnotetext{
Received March 2, 1990; revision accepted September 12, 1990.

David Foran's present address is Ludwig Institute for Cancer Research, 687 avenue des Pins ouest, Montreal, Quebec, Canada H3A $1 \mathrm{~A} 1$.
} 
The general inability to identify a mode of luminescence in myctophids and stomiiforms (as well as some other luminous fishes) has led to a default assumption that the fishes are themselves responsible for their luminescence, with the genes encoding luciferase residing on the fish chromosome (e.g., Hastings and Nealson, '80; Smith, '89). From this, two hypotheses can be proposed: 1) that these fishes have evolved their own method of luminescence (presumably independently as the myctophids and stomiiforms are not closely related) or 2) that these fishes have incorporated the genes necessary for luminescence via lateral gene transfer from luminous bacteria, circumventing the need for a symbiont. However, neither of these possibilities can be favored, in that the genes encoding luciferase have not been isolated.

Recently, a number of groups have succeeded in cloning into Escherichia coli the bacterial genes necessary for luminescence (Belas et al., ' 82 ; Cohn et al., '83; Engebrecht et al., '83; Delong et al., '87). In luminous bacteria, luciferase is a dimeric protein encoded by two linked genes termed $L u x$ $A$ and $L u x B$ (reviewed by Hastings et al., '85). The availability of these DNAs allows their use as probes to determine if homologous genes might be found in the tissues of myctophids or stomiiforms. If these fishes have incorporated the bacterial Lux genes into their genomes, one would expect to obtain a positive signal from all fish tissues examined. If previously undiscovered luminous bacteria are present in the light organs of these fishes, one would expect a positive signal only from those tissues containing light organs (the skin, and muscle to the extent the light organs are embedded in it) and a negative result from more internal tissues. Finally, if the fishes have evolved their own method of luminescence, one would expect a negative result from all fish tissues.

\section{MATERIALS AND METHODS \\ Isolation of fish genomic DNAs}

Fish samples were obtained by Karsten Hartel from the western North Atlantic. Animals were frozen on board ship and sent to Michigan, where they were stored at $-60^{\circ} \mathrm{C}$ until use. Once each fish was identified for family, genus, and/or species, DNA was isolated from skin, muscle, and brain. Over wet ice, skin from each animal was teased away from underlying muscle; immediately rinsed with cold, sterile, $100 \mathrm{mM}$ Tris, $\mathrm{pH}$
8, $100 \mathrm{mM}$ EDTA; and submerged in 1-2 $\mathrm{ml}$ of the same buffer. For muscle, remaining skin was scraped away and internal organs and head were removed, and the tissue was rinsed and submerged in $2-4 \mathrm{ml}$ of buffer. When possible, the skull was cleaned of all surrounding tissues and cut open from the spine, exposing brain tissue. This was removed and placed in buffer.

Tissues were ground for 5-20 sec at full speed with a Tek-Mar Tissumizer. Proteinase $\mathrm{K}$ and Sarcosyl were added to $100 \mu \mathrm{g} / \mathrm{ml}$ and $0.5 \%$, respectively, and samples were incubated at $55^{\circ} \mathrm{C}$ for $3 \mathrm{hr} ; 500 \mu \mathrm{g} / \mathrm{ml}$ of ethidium bromide was added to each sample, followed by $1 \mathrm{~g} / \mathrm{ml}$ of cesium chloride. Solution densities were determined and adjusted to $1.54-1.56 \mathrm{~g} / \mathrm{ml}$ if needed. Samples were centrifuged in a Beckman VTi 65 rotor at $55,000 \mathrm{rpm}, 21^{\circ} \mathrm{C}$, overnight. DNA was isolated, and a second centrifugation step was performed using a Beckman SW 60 rotor at $36,000 \mathrm{rpm}, 21^{\circ} \mathrm{C}$, overnight. The DNA band was again isolated, extracted repeatedly with watersaturated butanol to remove the ethidium bromide, and dialyzed extensively against $10 \mathrm{mM}$ Tris, pH 8, 1 mM EDTA.

\section{Construction of bacterial and fish clones to be used as probes}

The Vibrio fischeri Lux clone pJE205 (Engebrecht et al., '83) was obtained from K. Nealson. It was digested at the sites indicated in Figure 1 and ligated into Bluescript vector DNA (Stratagene Cloning Systems) using published protocols (Maniatis et al., ' 82 ). The ligation mixture was used to transform competent $E$. coli cells (XL1 blue, Stratagene). Plasmid DNAs from transformed bacteria were isolated by the alkaline lysis method (Maniatis et al., '82). In a similar manner, fragments of fish DNA were cloned for use as positive controls and to help quantitate the relative amount of DNA in a given lane on fish blots.

For use as probes, clones were digested with restriction enzymes that left only $20-50 \mathrm{bp}$ of vector DNA attached to the inserts, just enough so that vector sequences complementary to sequencing primers remained. Inserts were then electrophoresed through low-melting-point agarose (BRL) and isolated according to manufacturer's instructions. Approximately $100 \mathrm{ng}$ of the isolated fragment was heated to $100^{\circ} \mathrm{C}$ for $5 \mathrm{~min}$. An excess of primers complementary to both strands was added and the DNAs were radiolabeled by primer extension (Maniatis et al., '82). In the case of most probes, the primers utilized were the "SK" 
and "KS" primers of Stratagene. For the pSH700 probe, primers were synthesized that were complementary to sequences internal to the restriction sites.

\section{Blotting and probing of fish DNAs}

DNA samples were digested with a variety of restriction enzymes and electrophoresed through $0.8 \%$ (for enzymes recognizing six base sites) or $1.2 \%$ (four base sites) agarose gels. Gels were blotted using standard protocols (Maniatis et al., '82) onto Zetabind membrane filters (CUNO, Inc.) using $20 \times \mathrm{SSC}$ ( $3 \mathrm{M} \mathrm{NaCl}, 0.3 \mathrm{M}$ Na Citrate). Following transfer, filters were baked 1-2 hr under vacuum at $80^{\circ} \mathrm{C}$. Filters were prehybridized in $20-50 \mathrm{ml}$ of $0.5 \%$ nonfat dry milk, $2 \times \mathrm{SSC}, 1 \%$ sodium dodecyl sulfate (SDS) for $3-5 \mathrm{hr}$, and probes were hybridized in the same mixture. $\mathrm{Hy}-$ bridization criteria were varied depending on relatedness of filter DNAs and probes, and are described in the figure legends. After $24 \mathrm{hr}$, filters were washed in four changes of SSC and $0.1 \%$ SDS buffer (criteria dependent) and exposed to X-ray film.

\section{In situ hybridization of $\mathrm{pHU870}$ to fish tissues}

In situ hybridizations were conducted essentially as described by Hafen and Levine ('86). Small pieces of fish were covered with O.C.T. compound and frozen on dry ice. Sections were cut in a refrigerated cryostat at $-15^{\circ} \mathrm{C}$. After fixation of the sections, no subsequent treatments were performed prior to hybridizations. The probe was synthesized as described above, using $\alpha^{35}-\mathrm{S}$ dATP. Hybridizations were carried out at room temperature in $35 \%$ formamide, and following autoradiography, the slides were stained with azure B (Conn, '61) and photographed with a Zeiss Axioplan microscope.

\section{RESULTS}

\section{Preparation of fish samples}

DNA from fishes was isolated with careful attempts to minimize contamination of one tissue with another (see Materials and Methods), although the preservation of some samples was often less than ideal. Further, the light organs of these animals are generally embedded into the muscle, making it difficult to isolate muscle DNA free of light organ tissue. However, the proportion of light organ DNA should generally be higher in skin samples, and in the case of one large myctophid it was possible to isolate brain tissue that was completely free of contamination by other tissues. In this way, total DNA was isolated from a number of myctophids and stomiiforms representing the genera Photostomias, Chauliodus, Stomias, Gonostoma, and Argyropelecus.

\section{Survey of fish tissues}

The luciferase clone pJE205, isolated from $V i b$ rio fischeri, has been characterized (Engebrecht et al., '83) and the Lux A and Lux B genes sequenced (Foran and Brown, '88). A subclone of pJE205 containing only luciferase gene sequences (pHU870; Fig. 1) was used to probe a southern blot of Hind III-digested muscle and skin DNAs from a variety of luminous fishes. The results are shown in the middle panel of Figure 1. As is apparent, the probe hybridized to all tissues examined, although it should be stressed that these results are not quantitative; different amounts of total DNA exist in different lanes, even for a single animal. Further, the probe did not hybridize to control DNAs (e.g., herring and shad; data not shown). Note also that the same $5.2 \mathrm{~kb}$ band is generated in all samples. Similar results were obtained with other restriction enzymes (e.g., Apa I, Hha I, Ssp I), for which, again, the size of the hybridizing fragment, although varying between enzymes, was the same in all fishes.

To elucidate this result further, a muscle DNA sample from the myctophid represented in the middle panel of Figure 1 (lane 1) was digested with various enzymes, blotted, and probed with a second Lux subclone (pSH700). The hybridization, shown in the bottom panel of Figure 1, generated one or two bands of varying size with each enzyme, indicating that the signal obtained represents a single copy sequence. Further, the different patterns generated with Mbo I and Sau IIIA (lanes 7 and 8) suggest that the fragment to which the probe hybridizes is methylated.

\section{Quantitation of the signal generated by fish DNAs}

To examine quantitatively the signal obtained from the fish tissues, similar amounts of total DNA isolated from skin, muscle, and brain of this myctophid were digested with Sau IIIA, blotted, and probed with pHU870. The results are shown in Figure 2a. As is apparent, the skin DNA generated a strong signal, muscle a weaker signal, and no signal was seen in the brain sample, even with this long autoradiographic exposure. As a control, the same blot was stripped of old probe and rehybridized to a labeled fragment of single copy fish 

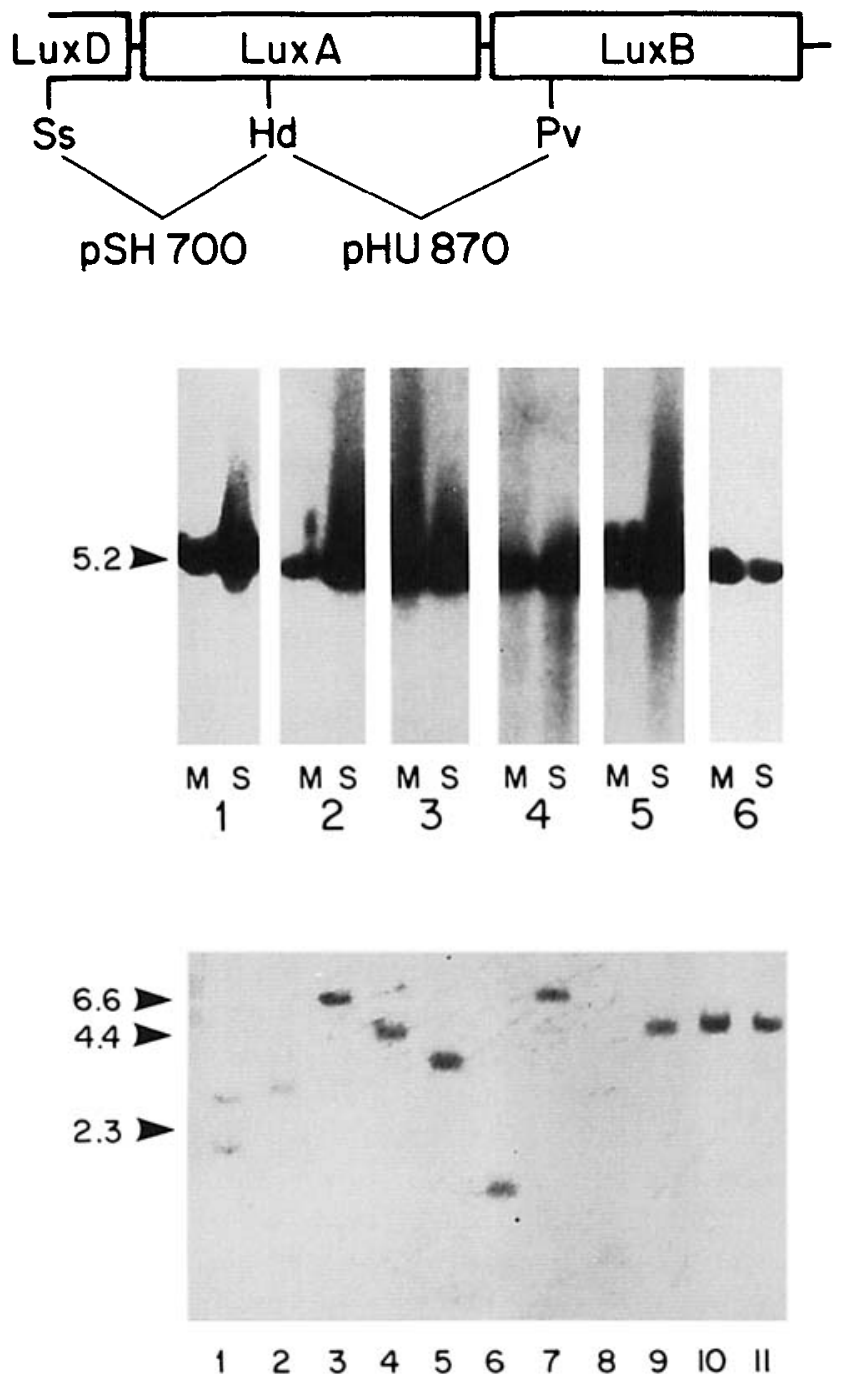

Fig. 1. Hybridization of bacterial Lux probes to Southern blots of myctophid and stomiiform DNAs. Top: Region of the Lux operon of Vibrio fischeri from which subclones were synthesized. Lux A and Lux B encode the $\alpha$ and $\beta$ subunits of bacterial luciferase; Lux D encodes another gene necessary for bacterial luminescence. The DNA fragments were subcloned at appropriate restriction sites (Ss, Sst I; Hd, Hind III; Pv, Pvu II). The size of the probe in base pairs is indicated in the fragment's name. Middle: Southern blot of Hind III digests of myctophid and stomiiform DNAs probed with pHU870. M, muscle DNA; S, skin DNA. The same amount of DNA was not loaded into each lane, so these results are not quantitative, even within a fish species. Samples 1 , a myctophid; 2, Photostomias; 3, Chauliodus; 4, Stomias; 5, Gonostoma; 6, Argyropelecus. The approximate size of the band in kilobases is shown at left. Hybridization criteria were $2 \times$ SSC, $60^{\circ} \mathrm{C}$. Bottom: Myctophid muscle DNA (as in lane 1 above) digested with a variety of enzymes and probed with pSH700 (lanes 1, Ava II; 2, Bgl I; 3, Bgl II; 4, Eco RI; 5, Eco RV; 6, Hae II; 7, Mbo I; 8, Sau IIIA; 9, Sst I; 10, Sst II; 11, Xba I). Hybridization criteria were $2 \times \mathrm{SSC}, 65^{\circ} \mathrm{C}$, and position of size standards in kilobases are indicated at left. genomic DNA, isolated from muscle of the same myctophid (Fig. 2b). Note that approximately equal amounts of fish DNA were present in all lanes, indicating that the signals generated with bacterial Lux probes (Fig. 2a) did not originate from the fish genome.

\section{In situ hybridizations of a Lux probe to fish sections}

It is well known that luminous marine bacteria can grow on fishes collected from the ocean (Harvey, '52), and the Southern blots described above do not exclude the possibility of bacterial contamination resulting in the signal generated from these fish samples. To locate precisely the source of the signal in Figures 1 and 2, and to ensure that it was not caused by bacteria that were simply contaminating the skin of the fishes, the Lux probe pHU870 (Fig. 1) was hybridized in situ to fish tissues. In most of these fishes the light organs are small, rather brittle photophores, which are not conducive to frozen sectioning. Further, the wall of the photophore is thick and darkly pigmented such that a signal generated by the radiolabeled probe is difficult to visualize against the black background. However, in the hatchet fishes (here Argyropelecus), large, ventral light organs exist, which are well suited for frozen sectioning and subsequent hybridization.

Results of these experiments are shown in Figure 3. Several sections through the same fish (the stomiiform Argyropelecus olfersi) were taken. As a control, some sections were probed with labeled vector DNA only, followed by staining with the basic dye azure B (Conn, '61). Although no hybridization was observed, the general structure of a light organ can be seen (Fig. 3a). The light organs themselves appear basically oval and are backed by a thin, darkly pigmented wall. Two differentially staining cell types are apparent in the light organs, which have been designated $\mathrm{A}$ and B "photocytes" by Bassot ('66) (indicated in Fig. 3a) and are probably secretory in nature. Muscle lies directly above the light organ, and skin is visible along external portions of the section.

When probed with pHU870 (Fig. 3b-d), extensive hybridization was observed (identifiable by the black grains over specific areas of the sections). Because in situ hybridizations are designed to localize the RNAs of expressed genes in a given tissue, the results indicate where and to what extent a gene is active. Hybridization occurred along the inner portions of the light organ walls and was not found on the skin of the fish 

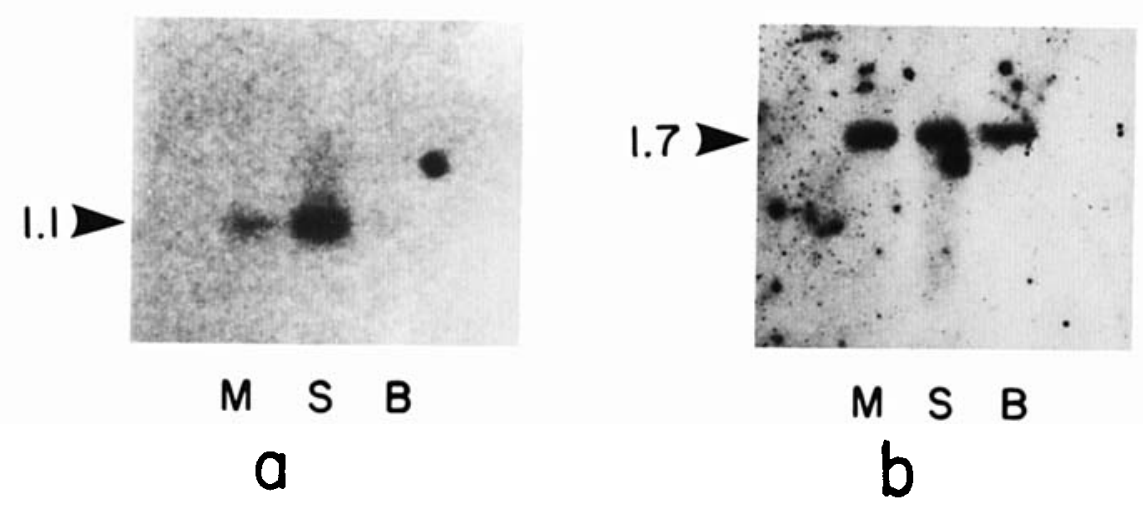

Fig. 2. Southern blot of skin (S), muscle (M), and brain (B) DNAs from an Atlantic myctophid, digested with Sau IIIA. a: The blot probed with pHU870 (hybridization criteria were $0.1 \times \mathrm{SSC}, 60^{\circ} \mathrm{C}$ ). b: The same blot as in a, stripped of old probe and rehybridized $\left(0.1 \times \mathrm{SSC}, 67^{\circ} \mathrm{C}\right)$ to a cloned fragment of myctophid DNA, showing that similar amounts of fish DNA exist in each lane. The sizes of the bands in kilobases are indicated.

(Fig. 3b). In general the signal was strongest adjacent to, but not directly over, A photocytes; this, when the section is through the correct plane (as in Fig. 3b), provides evidence that these light organs are interconnected. More detail can be seen in Figure 3c, where the lower light organ in Figure $3 \mathrm{~b}$ is shown under higher magnification. A similar situation is displayed in Figure $3 \mathrm{~d}$, with the lower light organ shown in Figure 3e.

\section{DISCUSSION}

The myctophids and stomiiforms represent two of the most common groups of luminous fishes, yet the nature of their luminescence has remained a mystery. By using cloned Lux genes from luminous marine bacteria as probes, I have attempted to distinguish among three possibilities: that luminous bacteria directly result in luminescence in these fishes, that the fishes genetically incorporated the genes necessary for luminescence via lateral gene transfer and no longer require luminous symbionts, or that these animals have evolved their own genes for luminescence apart from marine bacteria. It is a common assumption that, because bacteria have never been seen in or isolated from the light organs of certain luminous teleosts, the genes necessary for luminescence reside on the fish chromosome (e.g., Harvey, '52; Hastings and Nealson, '80; Smith, '89), but in no instances have these genes been cloned or otherwise identified, nor have the corresponding proteins.

The results presented here demonstrate positive hybridization of bacterial Lux probes to both DNAs and tissue sections containing the light organs of myctophids and stomiiforms, but not to other fish tissues. This indicates that luminescence in both myctophids and stomiiforms results from previously undetected luminous bacteria. Several points are worth mentioning, however. First is the uniformity of the signal generated in the wide variety of luminous fishes examined in Figure 1. These data directly argue against the DNA fragments to which the probe hybridized originating from the fish genome. Over the large evolutionary distances covered, one would surely expect enough sequence divergence to have occurred such that different chromosomal restriction patterns would exist among these fishes. However, there is always a possibility of laboratory contamination of samples with plasmid DNA, which could produce a common result. In this instance, contamination is ruled out in Figure 2 , where extremely different signals are generated by the different tissues. If a contaminant existed it would be found in skin, muscle, and brain DNAs of the myctophid, which were all prepared and electrophoresed with the same reagents. Here the brain sample is plainly negative. The most plausible explanation for the similarity of the signal among fishes in Figure 1 is that a common bacterium colonizes these fishes. All the animals shown were obtained at the same time from the same waters. Further, preliminary hybridization of pHU870 to Southern blots of skin and muscle DNAs from Pacific myctophids does not produce this signal (data not shown). The hybridizing DNA may lie on the bacterial chromosome or on a plasmid (which do exist in luminous bacteria), but it is plainly not part of the fish genome.

A second point of concern is possible contami- 

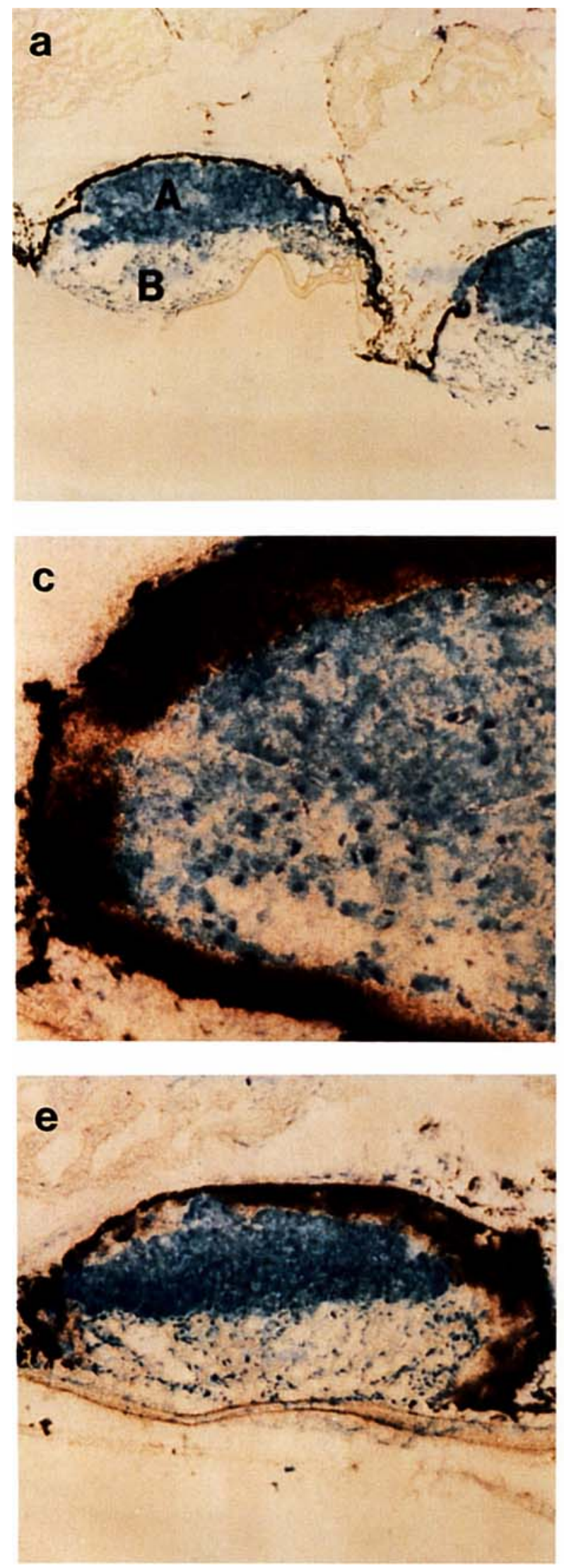
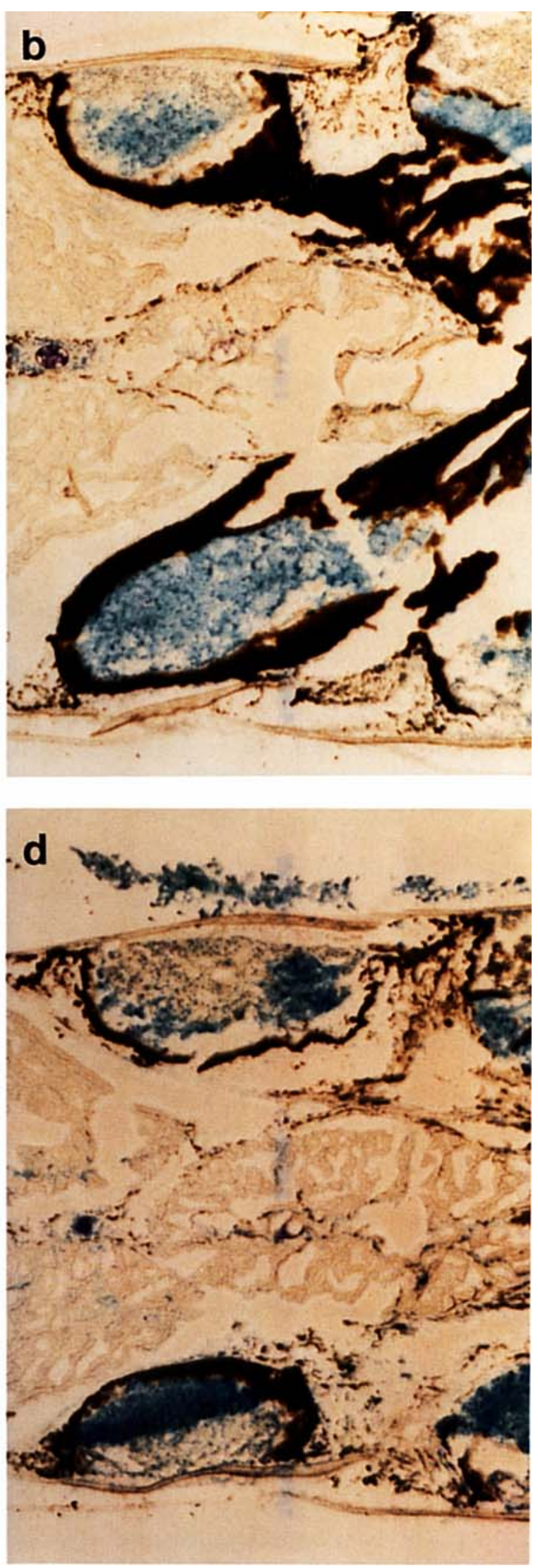

Figure 3 
nation of the fishes themselves by luminous bacteria, which are common in the oceans' waters. Although the results of Southern blot hybridizations do not exclude this possibility, the in situ hybridizations shown in Figure 3 do. As is apparent, hybridization of the Lux probe occurs at the light organs, whereas no signal above background is seen over other tissues. There is no indication of bacterial contaminants existing on the fish skin. Note also how far into the section the light organs are embedded, resulting in the positive signal in muscle DNAs in Figures 1 and 2.

The final question is, then, how might bacterial symbionts come to inhabit the photophores of myctophids and stomiiforms, and what form do they take. As mentioned, numerous investigators have studied the ultrastructure of these fishes without observing bacterial symbionts. Also, the types of light production in these animals, ranging from being slowly propagated along the fish to a quick flash, are thought not to be consistent with that of luminous bacteria, which generally produce a constant glow (Hastings and Nealson, '81). Perhaps, however, these discrepancies can be reconciled with the hybridization experiments presented. There are examples of animals harboring luminous bacterial symbionts where bacterial conformation and mode of light production appear to differ from the norm, one of which is luminous tunicates (Nealson and Hastings, '80). These chordates produce flashes of light, which is unusual in bacterial symbionts, and upon gentle homogenization of the animal the suspension glows constantly. However, the cell suspension tests negative in a bacterial luciferase assay. Only when sonicated is bacterial luciferase activity measurable (Nealson and Hastings, '80). The key seems to be that the symbionts are intracellular. Whatever regulation the symbionts are under is destroyed by homogenization of the tunicate, resulting in constant light, whereas the eukaryotic membrane surviving around the endosymbiont negates the bacterial luciferase assay until it is thoroughly sonicated.

It is still unknown, however, how or when these endosymbionts come to inhabit the tunicate light

Fig. 3. In situ hybridizations of pHU870 to sections of Argyropelecus olfersi. a: Control hybridization using vector DNA alone. $A$ and $B$ photocytes of the light organ are indicated. b, d: Sections through the ventral portion of the fish, probed with pHU870. c, e: Higher magnification of the lower light organs in $b$ and d, respectively. Magnifications: $a, \times 50$; b, $\times 50 ; c, \times 200 ; d, \times 50 ; e, \times 100$. organs. They may be similar to mitochondria or chloroplasts and hence be inherited cytoplasmically. This would necessitate the segregation of the symbionts to the light organ tissues during development, a situation similar to the proposed differential segregation of mitochondria in the tissues of other systems (Hauswirth and Laipis, '85). They may also be taken up from the ocean during the early stages of development. Likewise, it is not known how or when the proposed symbionts of myctophids and stomiiforms come to inhabit the light organs of the fishes. The identical hybridization patterns in the wide variety of fishes shown in Figure 1 indicate that symbionts were acquired from a common ocean population. Developmentally, fish light organs appear in early larval stages (Harvey, '52), and it would presumably be at this time that the first bacteria would come to occupy them. This set of symbionts could remain stable, or it might be replaced by subsequent infestations.

The light organs of myctophids and stomiiforms exist in a variety of forms and can be activated independently on each animal (Harvey, '52), raising further questions about light control and symbiont regulation. Because of the potential rapidity of light production in these animals, these organs must surely be under neural control; they can be experimentally excited by electrical stimulation (Harvey, '52). Structurally, they contain secretory cells (see, e.g., Fig. 3a) and also contain unique, darkly staining "granules" whose origin and function, although presumed to be intimately involved in luminescence, are unknown (Bassot, '66). However, as in the tunicates, there remains a gap in our knowledge of luminescence at this point. Growth and light production of luminous marine bacteria are influenced by oxygen and iron levels, by osmolarity, and by a substance termed autoinducer, which is produced by bacteria (reviewed by Hastings et al., '87). Obviously the fish host could potentially influence all these factors. The granules might act as storage sites for products produced by symbionts, or for fish secretory products necessary to stimulate the light or growth of symbionts. Based on in situ hybridizations, the proposed symbionts appear to exist adjacent to, not among, the $\mathrm{A}$ and $\mathrm{B}$ secretory cells of these fishes (Fig. $3 b-e$ ) and, like the secretory cells, are located in specific areas of the light organs, not throughout. Perhaps this arrangement offers clues to how the light organs function.

Finally, from the inability to culture or visual- 
ize bacterial symbionts in the light organs of myctophids and stomiiforms, it would seem that, in symbiosis, bacterial configuration is somehow altered. This could entail degradation of the bacterial wall, fusion with cells of the light organ, or some other mechanism that is not understood. Indeed, although a large variety of marine bacteria luminesce, only a subset of these are routinely isolated from light organs (Hastings and Nealson, '81). It may be that different bacteria, with their different growth characteristics and different kinetics of light production, have developed methods that, while allowing them to interact with myctophids and stomiiforms, leave them hidden from us. The experiments described here do signify, however, that bacterial symbionts give rise to luminescence in these common marine fishes. What form they take and how they might come to inhabit the fish light organs remains to be determined.

\section{ACKNOWLEDGMENTS}

I thank W. Fink, K. Hartel, and J. Paxton for help in obtaining and identifying fishes; S. Lewis and K. Nealson for providing bacterial DNAs; L. Bernstein for help with in situ hybridizations; and W. Cavenee, W. Fink, P. Foran, I. Gennett, J.W. Hastings, and J. Morin for reviewing and discussing the manuscript. This work was conducted in part in the laboratory of W.M. Brown at the University of Michigan (PHS grant GM30144).

\section{LITERATURE CITED}

Bassot, J. (1966) On the comparative morphology of some luminous organs. In: Bioluminescence in Progress. F. Johnson and Y. Haneda, eds. Princeton University Press, Princeton, NJ, pp. 557-610.

Belas, R., A. Mileham, D. Cohn, M. Hilmen, M. Simon, and M. Silverman (1982) Bacterial Bioluminescence: Isolation and expression of the luciferase genes from Vibrio harveyi. Science, 218:791-793.

Cohn, D.H., R.C. Odgen, J.N. Abelson, T.O. Baldwin, K.H. Nealson, M.I. Simon, and A.J. Mileham (1983) Cloning of the Vibrio harveyi luciferase genes: Use of a synthetic oligonueleotide probe. Proc. Natl. Acad. Sci. USA, 80:120-123.

Conn, H.J. (1961) Biological Stains. Williams and Wilkins Co., Baltimore, MD, pp. 99-100.

Delong, E.F., D. Steinhauer, A. Israel, and K.H. Nealson (1987) Isolation of the lux genes from Photobacterium Leiognathi and expression in Escherichia coli. Gene, 54:203210.

Engebrecht, J., K. Nealson, and M. Silverman (1983) Bacte- rial bioluminescence: Isolation and genetic analysis of functions from Vibrio fischeri. Cell, 32:773-781.

Foran, D.R., and W.M. Brown (1988) Nucleotide sequence of the LuxA and LuxB genes of the bioluminescent marine bacterium Vibrio fischeri. Nucleic Acids Res., 16:777.

Hafen, E., and M. Levine (1986) The localization of RNAs in Drosphila tissue sections by in situ hybridization. In: Drosophila, a Practical Approach. D.Roberts, ed. IRL Press, Washington, DC, pp. 139-157.

Harvey, E.N. (1952) Bioluminescence. Academic Press, New York.

Hastings, J.W. (1983) Biological diversity, chemical mechanisms, and the evolutionary origins of bioluminescent systems. J. Mol. Evol., 19:309-321.

Hastings, J.W., J.C. Makemson and P.V. Dunlap (1987) How are growth and luminescence regulated independently in light organ symbionts? Symbiosis, 4:3-24.

Hastings, J.W., and K.H. Nealson (1980) Exosymbiotic luminous bacteria occurring in luminous organs of higher animals. In: Endocytobiology, Endosymbiosis and Cell Biology. W. Schwemmler and H.E.A. Schenk, eds. Walter de Gruyter and Co., Berlin/New York, Vol. 1, pp. 467-471.

Hastings, J.W., and K.H. Nealson (1981) The symbiotic luminous bacteria. In: The Prokaryotes. M.P. Starr, H. Stolp, H.G. Truper, A. Balows, and H.G. Schlegel, eds. SpringerVerlag, Berlin, pp. 1332-1345.

Hastings, J.W., C.J. Potrikus, S.C. Gupta, M. Kurfurst, and J.C. Makemson (1985) Biochemistry and physiology of bioluminescent bacteria. Adv. Microb. Physiol., 26:235-291.

Hauswirth, W.W., and P.J. Laipis (1985) Transmission genetics of mammalian mitochondria: A molecular model and experimental evidence. In: Achievements and Perspectives of Mitochondrial Research. E. Quagliariello, E.C. Slater, F. Palmieri, C. Saccone, and A.M. Kroon, eds. Elsevier, Amsterdam/New York, pp. 49-59.

Haygood, M.G., and D.H. Cohn (1986) Luciferase genes cloned from the unculturable luminous bacteroid symbiont of the Caribbean flashlight fish, Kryptophanaron alfredi. Gene, 45:203-209.

Herring, P.J., and J.G. Morin (1978) Bioluminescence in fishes. In: Bioluminescence in Action. P.J. Herring, ed. Academic Press, London, pp. 272-329.

Jorgensen, J.C., and O. Munk (1979) Photophores and presumably luminous chin barbel and pectoral fin ray filaments of Thysanactis dentex (Pisces: Stomiatoidea). Acta Zool, 60:33-42.

Leisman, G., D. Cohn, and K. Nealson (1980) Bacterial origin of luminescence in marine animals. Science, 208:12711273.

Maniatis, T., E. Fritsch, and J. Sambrook (1982) Molecular Cloning: A Laboratory Manual. Cold Spring Harbor Laboratory, Cold Spring Harbor, New York.

Nealson, K.H., and J.W. Hastings (1980) Luminescent bacterial endosymbionts in bioluminescent tunicates. In: Endocytobiology, Endosymbiosis and Cell Biology. W. Schwemmler and H.E.A. Schenk, eds. Walter de Gruyter and Co., Berlin/New York, Vol. 1, pp. 461-466.

Smith, J.C. (1989) Generating novelty by symbiosis. Nature, 341:284-285. 